\title{
Cover Crop Performance between Plastic-mulched Beds: Impacts on Weeds and Soil Resources
}

\author{
Alyssa R. Tarrant, Daniel C. Brainard, and Zachary D. Hayden \\ Department of Horticulture, Michigan State University, 1066 Bogue Street, \\ East Lansing, MI 48823
}

Additional index words. living mulch, organic management, plasticulture, soil management

\begin{abstract}
Growing a cover crop living mulch between plastic-mulched beds may reduce soil erosion while providing other agroecosystem services. However, information regarding the relative differences among living mulch species to maximize services and minimize competition for nutrients and water in adjacent plastic-mulched beds is limited. A 2-year experiment in Michigan evaluated nine living mulch species for biomass production, inseason weed suppression, and potential for cash crop competition. Species included three warm season grasses \{Italian ryegrass [Lolium perenne L. ssp. multiflorum (Lam.) Husnot], teff [Eragrostis tef (Zuccagni) Trotter, and sudangrass [Sorghum bicolor (L.) Moench ssp. drummondii (Nees ex Steud.) de Wet \& Harlan]\}; three cool season grasses [barley (Hordeum vulgare $\mathrm{L}$.), rye (Secale cereale $\mathrm{L}$.), and wheat (Triticum aestivum $\mathrm{L}$.)]; and three clover species grown in combination with rye (Dutch white clover (Trifolium repens $\mathbf{L}$.), New Zealand white clover (T. repens L.) and yellow blossom sweet clover [Melilotus officinalis (L.) Lam.]\}. Although all living mulch treatments significantly reduced in-season weed biomass relative to the weedy control in 2018 , weeds were generally a dominant component of total biomass in all living mulch treatments other than teff. Weed biomass was negatively correlated with living mulch biomass, and teff exhibited both the greatest biomass and weed suppression in both years. However, despite spatial and physical separation, all living mulches demonstrated the potential to compete with a cash crop by reducing soil inorganic nitrogen and moisture levels in adjacent plastic mulch-covered beds. Growers interested in integrating living mulches into plasticulture systems must consider desired benefits such as enhanced weed suppression, soil quality, and harvesting conditions alongside potential risks to cash crop yields.
\end{abstract}

The use of plastic mulch film is standard practice in many conventional and organic fresh market vegetable production systems

Received for publication 2 Mar. 2020. Accepted for publication 30 Apr. 2020.

Published online 1 June 2020.

This paper is a portion of a thesis submitted by Alyssa R. Tarrant titled "Crop production and soil health tradeoffs of between-row weed and soil management strategies in organic plasticulture vegetable production" in partial fulfillment of requirements for the degree of Horticulture-Master of Science

This research was supported by funding from the Organic Agriculture Research and Extension Initiative (OREI) Grant No. 2016-04458 from the U.S. Department of Agriculture National Institute of Food and Agriculture, North Central Region Sustainable Agriculture Research and Education (NCR-SARE) project number GNC17-251, and Michigan State University AgBioResearch. We would like to thank Colin Phillippo, Victoria Lawless, Eryn Damon, Sam Callow, Genny Feister, Austin Green, and Patrick Squire for their help in the field and laboratory. Thanks also to Michael Metiva and Lisa Tiemann for comments on an early version of this manuscript. A.R.T. is a Graduate Research Assistant.

D.C.B. is an Associate Professor

Z.D.H. is an Assistant Professor.

A.R.T. is the corresponding author. E-mail: tarran19@ msu.edu.

This is an open access article distributed under the CC BY-NC-ND license (https://creativecommons. org/licenses/by-nc-nd/4.0/).
(Lamont, 2005; Tarara, 2000). Key benefits of plastic mulch include temperature moderation, increased moisture retention, reduced nutrient leaching, effective weed suppression in the crop row, and reduced soil splash that can lower incidence of some soil-borne diseases. These benefits often account for higher total and marketable vegetable yields in plasticulture production (Kasirajan and Ngouajio, 2012; Tarara, 2000).

Despite these advantages, soil erosion can be considerably greater in plasticulture systems, where the impervious surface of plastic-covered beds can induce aggressive runoff in the uncovered areas between beds (Steinmetz et al., 2016). This is particularly true when the soil in between-bed areas is left bare through the use of herbicides and cultivation to manage weeds (Steinmetz et al., 2016; Wan and El-Swaify, 1999). The concentration of water after precipitation events combined with the bare soil in between-bed areas can also increase the risk of leaching and runoff of pesticides and nutrients from plasticulture systems, with adverse consequences for local water resources (Arnold et al., 2004; Rice et al., 2004).

Growing a cover crop as a living mulch between plastic-mulched beds during cash crop production has the potential to mitigate these soil and nutrient conservation challenges, in addition to providing other services. These include weed suppression and organic matter contributions in intensive vegetable cropping systems or cool climates where it may otherwise be difficult to fit a productive cover crop in the rotation (Paine and Harrison, 1993; Rice et al., 2004; Sarrantonio, 1992; Snapp et al., 2005). Integrating a cover crop into a vegetable production system can be challenging because rotations are often diverse and complex, management is intensive, and the high value of vegetable crops can make removing land from production financially detrimental (Sarrantonio, 1992). These constraints can be further exacerbated in temperate climates where the growing season is already limited (Snapp et al., 2005). A living mulch between plastic-mulched beds allows for a soil-building cover crop to be grown alongside an income-generating cash crop. On the other hand, because living mulches grow simultaneously with a cash crop, competition for light or soil resources often lead to reductions in cash crop yields (Hartwig and Ammon, 2002; Lowry and Smith, 2018). However, plasticulture systems may be particularly suited for living mulch integration, with plastic mulch-covered raised beds providing both a spatial and physical barrier between a cash crop and living mulch or weeds growing in the between-bed area. Although this separation has the potential to reduce risks of competition relative to a nonplasticulture living mulch system, previous studies have demonstrated that cash crop yield reductions often do occur when living mulches are grown between plastic-mulched beds (Butler, 2012; Law et al., 2006; Nelson and Gleason, 2018; Reid, 2015; Reid and Klotzbach, 2013; Reiners and Wickerhauer, 1995; Warren et al., 2015).

Species selection is likely an important factor in maximizing potential benefits while minimizing production risks from living mulches in plasticulture systems. An ideal living mulch is one that is competitive enough to suppress weeds, while limiting interference with a cash crop (Hartwig and Ammon, 2002). Plant traits that are likely to balance weed suppression and cash crop interference include 1) rapid germination and establishment to exclude weeds, 2) a low and easily managed growth habit, 3) thorough soil coverage, and 4) resistance to drought and low-nutrient environments (Adamczewska-Sowińska et al., 2009; Brennan and Smith, 2018; den Hollander et al., 2007; Hartwig and Ammon, 2002; Leary and DeFrank, 2000). Although a single living mulch species may not possess all of these desired characteristics, various species and plant functional groups exhibit distinctive strengths and weaknesses influencing their suitability as a living mulch. For example, clovers are commonly used legume living mulch species because they have a relatively low growth habit, produce a groundcovering canopy, and have the ability to fix atmospheric $\mathrm{N}$, making them potentially more adaptable to low-fertility environments and less likely to compete with a cash crop for $\mathrm{N}$ than grasses (Hartwig and Ammon, 2002). However, many clovers are slower 
growing, and often outcompeted by aggressive summer annual weeds (MacLaren et al., 2019). In contrast, when planted in the appropriate climatic niche, many warm season grasses, such as sudangrass, Italian ryegrass, and teff, can establish quickly and accumulate larger amounts of biomass, improving their weed suppressive potential (Wedryk and Cardina, 2012). Although, high living mulch biomass production can lead to management difficulties, including increased mowing requirements and a greater potential for competition, which may increase the risk of cash crop yield reductions. Finally, many cool season winter annual grasses, such as cereal rye, winter wheat, and winter barley, have the advantage of establishing quickly while also remaining low-growing in the absence of a vernalization period (Brainard and Bellinder, 2004; Lowry and Smith, 2018; Nelson et al., 2011). When planted in the warm summer months, however, high temperatures can limit growth and competitiveness relative to many summer annual weeds (Brainard et al., 2012). In addition to trait-focused tradeoffs, the cost of seed, management requirements, and suitability to climate and cropping system context are also important considerations in living mulch species selection.

Previous living mulch studies outside of plasticulture systems have investigated strategies to mediate competition between a living mulch and cash crop, including species selection, use of supplemental nutrients and irrigation, delayed planting or early termination of the living mulch, spatial separation between the living mulch and the cash crop, and complementary weed management practices such as cultivation or herbicides (Brainard and Bellinder, 2004; Pfeiffer et al., 2016; Walters and Young, 2008). Within the context of a plasticulture system, Warren et al. (2015) found higher rates of an organic fertilizer eliminated yield reductions due to an Italian ryegrass/clover living mulch in plasticulturegrown broccoli in 1 of 2 years. Broccoli leaf chlorophyll (SPAD) measurements supported the hypothesis that competition for soil $\mathrm{N}$ was a factor in yield reductions, and the authors speculated that conditions encouraging living mulch root incursion under plastic-covered raised beds (e.g., low precipitation) may have contributed to differences in the severity of competition between the 2 years. Similarly, other studies in plasticulture vegetable production systems have reported variable impacts of living mulches on cash crop yields that may be attributed to interseasonal weather conditions or cash crop and living mulch species selection (Butler, 2012; Law et al., 2006; Miles, 2012; Nelson and Gleason, 2018; Reid, 2015; Reid and Klotzbach, 2013; Reiners and Wickerhauser, 1995; Warren et al., 2015). However, few studies have compared living mulch species side-by-side in plasticulture systems to evaluate whether differences in species functional characteristics may lead to innate differences in their potential to compete with a cash crop for soil resources (Miles, 2012; Reid 2015).
Although growers are interested in mixed plastic mulch-living mulch systems, they lack information to help optimize living mulch species choices and complementary management strategies that balance weed suppression and potential cash crop competition. The objective of this study was to evaluate nine cover crop species from three plant functional groups (cool season grasses, warm season grasses, and clovers) for their performance as living mulches in organic plasticulture production systems with respect to biomass production, weed suppression, and their potential to compete for in-bed soil moisture and $\mathrm{N}$ resources.

\section{Materials and Methods}

Site description. This study was conducted at the Michigan State University Horticulture Teaching and Research Center in Holt, MI (lat. $42^{\circ} 67^{\prime \prime} \mathrm{N}$, long. $84^{\circ} 48^{\prime \prime} \mathrm{W}$ ) on separate but adjacent organically managed fields in 2017 and 2018, both characterized by Spinks loamy sand (sandy, mixed, mesic Lamellic Hapludalf). Before the experiment began in 2017 the organic matter was $1.7 \%$ with $\mathrm{pH}$ of 6.5 and cation exchange capacity (CEC) of $3.7 \mathrm{cmol} \cdot \mathrm{kg}^{-1}$. Initial $\mathrm{P}, \mathrm{K}$, and $\mathrm{Mg}$ levels were 81,60 , and $64 \mathrm{mg} \cdot \mathrm{kg}^{-1}$ respectively. In 2018, initial soil chemical characteristics were as follows: $1.7 \%$ organic matter; pH 7.4; CEC $5.0 \mathrm{cmol} \cdot \mathrm{kg}^{-1}$; and $\mathrm{P}$, $\mathrm{K}$, and $\mathrm{Mg}$ levels of 153,127 , and $98 \mathrm{mg} \cdot \mathrm{kg}^{-1}$ respectively.

Experimental design. We evaluated three species from three distinct functional groups (cool season grasses, warm season grasses, and legumes), totaling nine cover crop species, for their potential as a living mulch grown between plastic-mulched beds (Table 1). Living mulches included three cool season grasses (cereal rye, winter barley, and winter wheat), three warm season grasses (Italian ryegrass, teff, and sudangrass) and three legumes grown in combination with a rye nurse crop (Dutch white clover, New Zealand white clover, and yellow blossom sweet clover). All clover seed was pretreated with rhizobium inoculum (Prevail; Verdesian Life Sciences, Cary, NC) and seeded with cereal rye to act as a nurse crop (Chase and Mbuya, 2008). Sudangrass was not included in 2018 because it had a tall growth habit that was difficult to manage, making it unsuitable for our intended purpose. Living mulches were compared with a cultivated (handhoed) control in both years, and to a weedy check in 2018.

Treatments were arranged in a randomized complete block design with four replications. Individual plots were $5.5 \mathrm{~m}$ long in 2017 and $6.1 \mathrm{~m}$ long in 2018, and consisted of three plastic-mulched beds and two betweenbed areas. Between-bed areas measured $\approx 1 \mathrm{~m}$ wide.

A cash crop was not included in this study because we were interested in evaluating relative differences between living mulches' use of in-bed resources. Because a variety of vegetable crops are commonly grown in plasticulture, it was our goal to eliminate cash crop and living mulch root-to-root interactions to broadly identify living mulch species that may be more or less competitive with any vegetable crop.

Field management. In late May of both years, Nature Safe (Irving, TX) organic AllSeason Fertilizer 10-2-8 (N-P-K) was broadcast applied at $56 \mathrm{~kg}$ total $\mathrm{N} / \mathrm{ha}$ and incorporated with a rototiller. The fertilizer is derived from feather meal, meat and bone meal, blood meal, and sulfate of potash. We applied 1.22-m-wide, $0.025-\mathrm{mm}$ (1 mil) black embossed plastic mulch (Trickl-Eez Irrigation Inc., St. Joseph, MI) within a day of field fertilization using a tractor mounted plastic layer (Model 2600 series II Plastic Layer; Rain-flow Irrigation, East Earl, PA). Plastic-mulched beds were raised to $0.15 \mathrm{~m}$ and laid on 1.67-m centers, resulting in 0.61$\mathrm{m}$-wide bed tops. Single drip irrigation lines with $30-\mathrm{cm}$ emitter spacing were installed simultaneously under the plastic mulch.

Living mulch treatments were broadcast sown and lightly incorporated with a rake on 30 May of both years. Cultivated and weedy treatments were similarly raked at the time of seeding. Seeding rates (Table 1) were selected based on the highest recommended rates (Clark, 2007; Lindquist, 2015). Due to poor establishment of cool season grasses in 2017, we decided to increase the seeding rate in 2018 . In $2017,4.0 \mathrm{~mm}$ of overhead irrigation was applied after 5 days of no rain to encourage living mulch germination and another $4.8 \mathrm{~mm}$ of water was applied 1 week later. Overhead irrigation was not necessary in 2018 , with $\approx 19 \mathrm{~mm}$ of rain the evening after planting and a total of $33.5 \mathrm{~mm}$ of rain the week after living mulch sowing. For the duration of the experiment, in-bed drip irrigation was applied at a rate of $\approx 6.3 \mathrm{~mm}$ weekly to observe relative differences in inbed soil moisture depletion across treatments.

A walk-behind rotary mower (11732 SelfPropel Rear Wheel Drive Mower; LawnBoy, Plymouth, WI) with the mower deck set to a $10-\mathrm{cm}$ cutting height was used to manage living mulches and weeds. Mowing occurred when the heights of the tallest plants were $\approx 30$ to $50 \mathrm{~cm}$ above the level of plasticmulched beds because this is likely when a grower would intervene to maintain workable between-bed areas and avoid light competition with a cash crop. The tallest plants in the between-bed area were typically broadleaf weeds, resulting in all living mulches and the weedy check treatments being mowed at the same time. On the basis of this criterion, we mowed a total of three times in each growing season, starting at the beginning of July, with 2 to 3 weeks between mowing events. Cultivated control plots were maintained through hand hoeing every 2 to 3 weeks.

Data collection. Weed and living mulch density counts were taken 3 weeks after living mulch sowing in 2017 and 2 weeks after sowing in 2018. In 2017, density was evaluated by category from two quadrats measuring $1 \mathrm{~m} \times 0.25 \mathrm{~m}$ in the between-bed 


\begin{tabular}{|c|c|c|c|c|c|c|}
\hline \multirow[b]{3}{*}{ Common name } & \multirow[b]{3}{*}{ Scientific name } & & \multicolumn{2}{|c|}{ Seeding rate } & & \\
\hline & & & 2017 & 2018 & \multicolumn{2}{|c|}{ Seed $\operatorname{cost}^{\mathrm{z}}$} \\
\hline & & Cultivar & \multicolumn{2}{|c|}{$\mathrm{kg} \cdot \mathrm{ha}^{-1}$} & $\$ / \mathrm{kg}$ & \$/ha \\
\hline Italian Ryegrass & Lolium perenne L. ssp. multiflorum (Lam.) Husnot & Tetila & 35.9 & 35.9 & 3.30 & 61.60 \\
\hline Teff & Eragrostis tef (Zuccagni) Trotter & Dessie & 11.2 & 11.2 & 9.24 & 54.04 \\
\hline Sudangrass & $\begin{array}{l}\text { Sorghum bicolor (L.) Moench ssp. drummondii } \\
\text { (Nees ex Steud.) de Wet \& Harlan }\end{array}$ & Piper & 56.1 & - & 6.01 & 175.95 \\
\hline Barley & Hordeum vulgare L. & Thoroughbred & 168.1 & 336.3 & 0.92 & $160.98^{y}$ \\
\hline Rye & Secale cereal L. & $\mathrm{VNS}^{\mathrm{x}}$ & 168.1 & 336.3 & 0.81 & 142.95 \\
\hline Wheat & Triticum aestivum $\mathrm{L}$. & Emerson & 168.1 & 336.3 & 0.99 & 173.86 \\
\hline White clover & Trifolium repens $\mathrm{L}$. & Dutch-VNS ${ }^{w}$ & $22.4(84.1)$ & $22.4(168.1)$ & 11.44 & $205.29^{v}$ \\
\hline White clover & Trifolium repens $\mathrm{L}$. & New Zealand-Crusadew & $22.4(84.1)$ & $22.4(168.1)$ & 8.36 & 169.27 \\
\hline Yellow clover & Melilotus officinalis (L.) Lam. & Sweet blossom-VNS ${ }^{w}$ & $22.4(84.1)$ & $22.4(168.1)$ & 3.74 & 115.22 \\
\hline
\end{tabular}

${ }^{\mathrm{z}}$ Seed cost is an estimate based on the retail price paid for untreated seed used in this study. Cost on a per hectare basis considers living mulch is only planted in between-bed areas and thus is dependent on bed width and between-bed spacing.

${ }^{\mathrm{y}}$ Barley, rye, and wheat $\$ /$ ha calculated using highest seeding rate during the study (2018 seeding rates).

${ }^{\mathrm{x}}$ Variety not stated.

${ }^{\mathrm{w}}$ Clovers seeded with a half rate of rye monoculture; number in parentheses represents rye seeding rate in mixture.

${ }^{\mathrm{v}} \mathrm{Seed}$ cost for clover-rye mixtures only accounts for clover seed price.

areas of each plot. Weeds and living mulch categories included grass living mulch, clover living mulch, lambsquarters (Chenopodium album L.), pigweeds (Amaranthus spp.), weeds in the Polygonaceae family, nightshades (Solanaceae spp.), other broadleaf weeds, and other grass weeds. Due to small seedling size and high densities, clover living mulch individuals were counted in four randomly selected $2.54 \mathrm{~cm} \times 2.54 \mathrm{~cm}$ quadrats. In 2018, density counts were taken in two $0.25 \mathrm{~m} \times 0.50 \mathrm{~m}$ quadrats per plot and were separated into grass living mulch, clover living mulch, lambsquarters, pigweeds, purslane (Portulaca oleracea L.), other broadleaf weeds, and other grass weeds. Categories for weed density counts were selected based on the weeds that were most abundant and consistent across the field in each year. We did not evaluate teff densities in either year due to challenges associated with small seedling size and high densities which made accurate counts difficult.

An estimate of weed and living mulch aboveground biomass production was assessed using a permanently placed $0.25 \mathrm{~m} \times 0.50 \mathrm{~m}$ quadrat in each between-bed area per plot. Samples were taken by clipping aboveground biomass at a $10 \mathrm{~cm}$ height immediately before each of the first two mowing events and to the ground at experiment termination. Biomass was not sampled before the third mowing event in either year due to labor constraints. Therefore, total season aboveground biomass data represent an underestimate of actual biomass produced. Aboveground biomass was separated into grass living mulch, clover living mulch, and total weed biomass, then dried to a constant weight at $60{ }^{\circ} \mathrm{C}$ before dry weight determination. We measured living mulch and weed heights before the first mowing event in both years. Heights were collected by randomly placing a meter stick perpendicular to the ground in between-bed areas and determining the height of the nearest weed and living mulch plant. This process was repeated six times per plot.

To quantify the potential for living mulch treatments to compete with a cash crop for in- bed soil resources, in-bed soil inorganic $\mathrm{N}$ levels were quantified from samples taken to $20 \mathrm{~cm}$ depth at monthly intervals starting at trial establishment. Soil samples were composites of 10 cores per plot taken from the center plastic-mulched bed. Soil samples were stored at $4{ }^{\circ} \mathrm{C}$ until being dried at $38{ }^{\circ} \mathrm{C}$ for at least $36 \mathrm{~h}$. Inorganic $\mathrm{N}$ was extracted from $10 \mathrm{~g}$ dry soil using $50 \mathrm{~mL} 1 \mathrm{M}$ $\mathrm{KCl}$. Extracts were analyzed for $\mathrm{NO}_{3}{ }^{-}$and $\mathrm{NH}_{4}{ }^{+}$concentrations using a Lachat injection flow autoanalyzer (Lachat QuickChem; Hach Company, Loveland, CO). In-bed soil moisture in the top $20 \mathrm{~cm}$ of soil was monitored on a biweekly basis using a FieldScout timedomain reflectometer probe (Spectrum Technologies Inc., Aurora, IL). Ten measurements in the center plastic-mulched bed were taken per plot and averaged before analysis.

Statistical analysis. Given the differences in the treatments evaluated between years, the 2 years of data collected were analyzed separately. A mixed-model analysis of variance (ANOVA) was used to determine the effect of between-bed management strategy on living mulch and weed densities, living mulch and weed aboveground biomass production, in-bed soil inorganic $\mathrm{N}$, and in-bed soil moisture using the MIXED procedure in SAS (Version 9.4; SAS Institute, Cary, NC). Treatment was included as a fixed factor and block (replication) as a random factor in all analyses. Because we were also interested in evaluating differences between living mulch functional groups, treatment data were pooled into five functional groupings (cool season grasses, warm season grasses, clovers, weedy, and cultivated) and a separate ANOVA was conducted with functional group as a fixed factor and block as a random factor. Total in-bed soil inorganic $\mathrm{N}$ and soil moisture data were subjected to a repeatedmeasures mixed-model ANOVA using the MIXED procedure in SAS, with date treated as a fixed factor. A first-order autoregressive variance-covariance structure was used in the repeated measures analysis. When necessary, data were either log transformed or an unequal variance model used to meet assumptions of normality and equal variance. Data presented are not transformed. Unless otherwise noted in the text, where ANOVA results were significant $(P \leq 0.05)$, mean separations were conducted using Fisher's protected least significant difference test at $P \leq 0.05$.

To evaluate the relationship between weed and living mulch biomass, biomass data in living mulch plots were combined across years and a correlation analysis was conducted ( $\mathrm{R}$ Foundation for Statistical Computing, Vienna, Austria) using the R function cor.test in the package ggpubr (Kassambara, 2020). Because living mulch biomass data were not normally distributed, Spearman's rank-order correlation was used. The cultivated control and weedy check treatments were not included in this analysis.

\section{Results}

Weather. Average May-August temperatures were similar in both years and comparable to 30-year averages, with the exception of relatively higher temperatures in May 2018 (Table 2). Similarly, May precipitation in 2018 was greater than in 2017 and above 30 -year averages (Table 2). In the week after living mulch sowing in 2018, the field received a total of $33.5 \mathrm{~mm}$ of rain. In contrast, 2017 was drier during living mulch establishment, with only $1.5 \mathrm{~mm}$ of precipitation and $4.0 \mathrm{~mm}$ of supplemental overhead irrigation within 1 week of sowing. However, precipitation in June and July of 2017 far exceeded that in 2018 .

Living mulch and weed density. The densities of living mulch species taken early in the season differed by species and were likely influenced by the number of seeds sown (as determined by cover crop seed size and sowing rate) and environmental conditions in each study year (Table 3). Although statistical comparisons were not made between years, cool season grass densities were notably greater in 2018 compared with 2017 (Table 3), likely reflecting the higher seeding rates used in that year. However, ryegrass densities were also higher in 2018 relative to 2017 despite similar seeding rates, suggesting 
that environmental conditions (e.g., higher soil moisture) may have also contributed to better living mulch establishment in that year. In contrast, 2018 densities of clover species in clover-rye mixtures were either lower than (Dutch white clover and New Zealand white clover) or comparable to (yellow clover) densities in 2017. One possibility for this effect was the higher rye seeding rates used in the clover-rye mixtures in 2018 may have contributed to increased interspecific competition and lower clover emergence compared with 2017.

Ambient weed pressure was high in both experiment years, with early season densities in cultivated treatments averaging 304 weeds $/ \mathrm{m}^{2}$ in 2017 and 1430 weeds $/ \mathrm{m}^{2}$ in 2018 (Table 3). In 2017, no living mulch treatment reduced early season weed density compared with the cultivated treatment (density counts were taken before first cultivation) in the absence of a weedy check in this

Table 2. Monthly average temperatures and total precipitation during the 2017 and 2018 seasons and 30 -year averages.

\begin{tabular}{lccccccc}
\hline & \multicolumn{3}{c}{ Temperature $\left({ }^{\circ} \mathrm{C}\right)$} & & \multicolumn{3}{c}{ Precipitation $(\mathrm{mm})$} \\
\cline { 2 - 4 } \cline { 6 - 8 } Month & 2017 & 2018 & $30 \mathrm{yr}^{\mathrm{z}}$ & & 2017 & 2018 & $30 \mathrm{yr}$ \\
\hline May & 13.5 & 17.6 & 14.7 & & 65.8 & 121.8 & 84.6 \\
June & 19.9 & 20.0 & 20.0 & & $92.5^{\mathrm{y}}$ & 37.2 & 88.9 \\
July & 21.6 & 21.9 & 22.1 & & 67.3 & 26.2 & 82.8 \\
August & 19.3 & 21.8 & 21.3 & & 34.8 & 112.5 & 83.8 \\
\hline
\end{tabular}

${ }^{\mathrm{z}}$ Thirty-year average temperature and precipitation reported by National Oceanic and Atmospheric Administration for East Lansing, Michigan, from 1981 to 2010. Retrieved from https://www.ncdc. noaa.gov/cdo-web/datatools/normals; verified on 12 Mar. 2019.

${ }^{\mathrm{y}}$ June 2017 precipitation total includes $8.8 \mathrm{~mm}$ of water applied as two overhead irrigation events within 2 weeks of sowing living mulches on 30 May 2017.

Table 3. Living mulch and weed densities evaluated within 3 weeks of living mulch sowing.

\begin{tabular}{|c|c|c|c|c|}
\hline \multirow[b]{3}{*}{ Treatment } & \multicolumn{2}{|c|}{ Living mulch density ${ }^{2}$} & \multicolumn{2}{|c|}{ Weed density } \\
\hline & 2017 & 2018 & $\overline{2017}$ & 2018 \\
\hline & \multicolumn{4}{|c|}{ Plants $/ \mathrm{m}^{2}$} \\
\hline Cultivated & - & - & $304^{y}$ & $1430 a^{x}$ \\
\hline Weedy & - & - & $-^{\mathrm{w}}$ & $1299 \mathrm{ab}$ \\
\hline Ryegrass & $362 \mathrm{c}$ & $1006 \mathrm{abc}$ & 359 & $951 \mathrm{bcd}$ \\
\hline Teff & $-^{\mathrm{v}}$ & - & 277 & $887 \mathrm{~cd}$ \\
\hline Sudangrass & $301 \mathrm{c}$ & ${ }^{\mathrm{u}}$ & 218 & - \\
\hline Barley & $347 \mathrm{c}$ & $1423 \mathrm{a}$ & 330 & $829 \mathrm{~cd}$ \\
\hline Rye & $238 \mathrm{c}$ & $554 \mathrm{c}$ & 370 & $886 \mathrm{~cd}$ \\
\hline Wheat & $278 \mathrm{c}$ & $1274 \mathrm{a}$ & 296 & $743 \mathrm{~cd}$ \\
\hline Dutch white clover & $2350 \mathrm{a}$ & $1410 \mathrm{a}$ & 222 & $564 \mathrm{~d}$ \\
\hline New Zealand white clover & $2272 \mathrm{a}$ & $1168 \mathrm{ab}$ & 238 & $983 \mathrm{bc}$ \\
\hline Yellow sweet blossom clover & $726 \mathrm{~b}$ & $682 \mathrm{bc}$ & 197 & $736 \mathrm{~cd}$ \\
\hline
\end{tabular}

${ }^{\mathrm{z}}$ Living mulch densities reported for clover treatments refer to density of clover species only. Cereal rye density in mixture with clovers was not significantly different between clover treatments and averaged 113 and 264 rye plants $/ \mathrm{m}^{2}$ in 2017 and 2018, respectively.

${ }^{\mathrm{y}}$ Weed density in cultivated plots was taken before the first cultivation.

${ }^{\mathrm{x}}$ Means within the same column followed by the same letter are not significantly different according to Fisher's protected least significant difference test $(P \leq 0.05)$.

${ }^{\mathrm{w}} \mathrm{A}$ weedy check was not included in 2017.

${ }^{\mathrm{v}}$ Teff densities were not collected due to small seedling size and high densities which made accurate counts difficult.

"Sudangrass was not included in 2018.

year. In 2018, all living mulch treatments reduced early season weed densities compared with the cultivated treatment, although weed densities in the New Zealand white clover and ryegrass treatments were comparable to the weedy check (Table 3 ).

Living mulch and weed biomass production. Biomass production is represented by biomass collections taken before the first two mowing events and at experiment termination. Biomass samples were not collected before the third mowing event, and thus biomass production estimates are likely underestimated. When analyzed by functional group, warm season grasses produced more aboveground biomass (175 and $381 \mathrm{~g} \cdot \mathrm{m}^{-2}$ in 2017 and 2018, respectively) than cool season grasses $(15$ and $126 \mathrm{~g} \cdot \mathrm{m}^{-2}$ in 2017 and 2018) or cloverrye mixtures (70 and $165 \mathrm{~g} \cdot \mathrm{m}^{-2}$ in 2017 and $2018)$ in both years $(P<0.01$, data not shown). Aboveground biomass accumulation by cloverrye mixtures was significantly greater than cool season grasses in 2017, but statistically comparable between the two functional groups in 2018.

Differences in biomass production were also observed within functional groups and among individual species. For example, within warm season grasses, teff produced more biomass than ryegrass in both years, although sudangrass biomass was comparable to teff in 2017 (Table 4). Similarly, barley consistently accumulated more biomass than rye or wheat (Table 4). In contrast, no differences in clover or total living mulch (clover and rye) biomass were detected among clover-rye mixtures (Table 4).

Cumulative combined weed and living mulch biomass production ranged from 473 to $595 \mathrm{~g} \cdot \mathrm{m}^{-2}$ and from 429 to $721 \mathrm{~g} \cdot \mathrm{m}^{-2}$ in 2017 and 2018, respectively (Fig. 1). Because biomass was not collected at the third mowing event, these values are underestimates of true biomass accumulation. In 2017, despite differences in living mulch biomass production, combined living mulch and weed biomass was similar across all living mulch treatments other than ryegrass and Dutch white clover treatments, which had less total biomass than teff (Fig. 1). In other words, although living mulch treatments varied in the proportion of living mulch and weed biomass, nearly all resulted in the same

Table 4. Cumulative living mulch (cover crop) aboveground biomass production during the summer.

\begin{tabular}{|c|c|c|c|c|}
\hline \multirow[b]{3}{*}{ Living mulch treatment } & \multicolumn{2}{|c|}{2017} & \multicolumn{2}{|c|}{2018} \\
\hline & Total living mulch biomass & Clover biomass $^{z}$ & Total living mulch biomass & Clover biomass \\
\hline & & & & \\
\hline Ryegrass & $96.99 \mathrm{bc}^{y}$ & - & $202.09 \mathrm{bc}$ & - \\
\hline Teff & $262.60 \mathrm{a}$ & - & $559.61 \mathrm{a}$ & - \\
\hline Barley & $35.87 \mathrm{e}$ & - & $210.85 \mathrm{~b}$ & - \\
\hline Rye & $8.54 \mathrm{f}$ & - & $114.29 \mathrm{~cd}$ & - \\
\hline Wheat & $0.69 \mathrm{f}$ & - & $52.92 \mathrm{~d}$ & - \\
\hline Yellow sweet blossom clover & $50.67 \mathrm{de}$ & 46.84 & $206.85 \mathrm{~b}$ & 125.02 \\
\hline
\end{tabular}

${ }^{\mathrm{z}}$ Clover biomass production in the clover-rye mixtures. Total living mulch values for these treatments represent the sum of clover and rye biomass.

${ }^{\mathrm{y}}$ Means within the same column followed by the same letter are not significantly different according to Fisher's protected least significant difference test $(P \leq$ $0.05)$. 


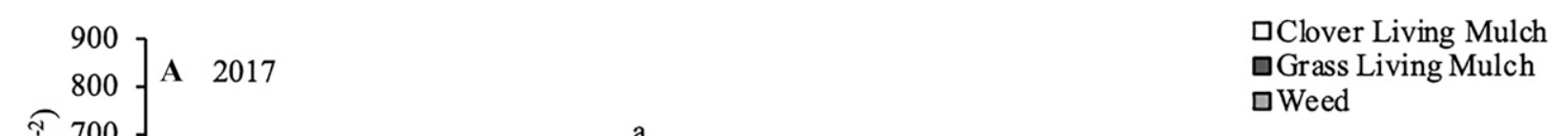

$\square$ Grass Living Mulch

口Weed
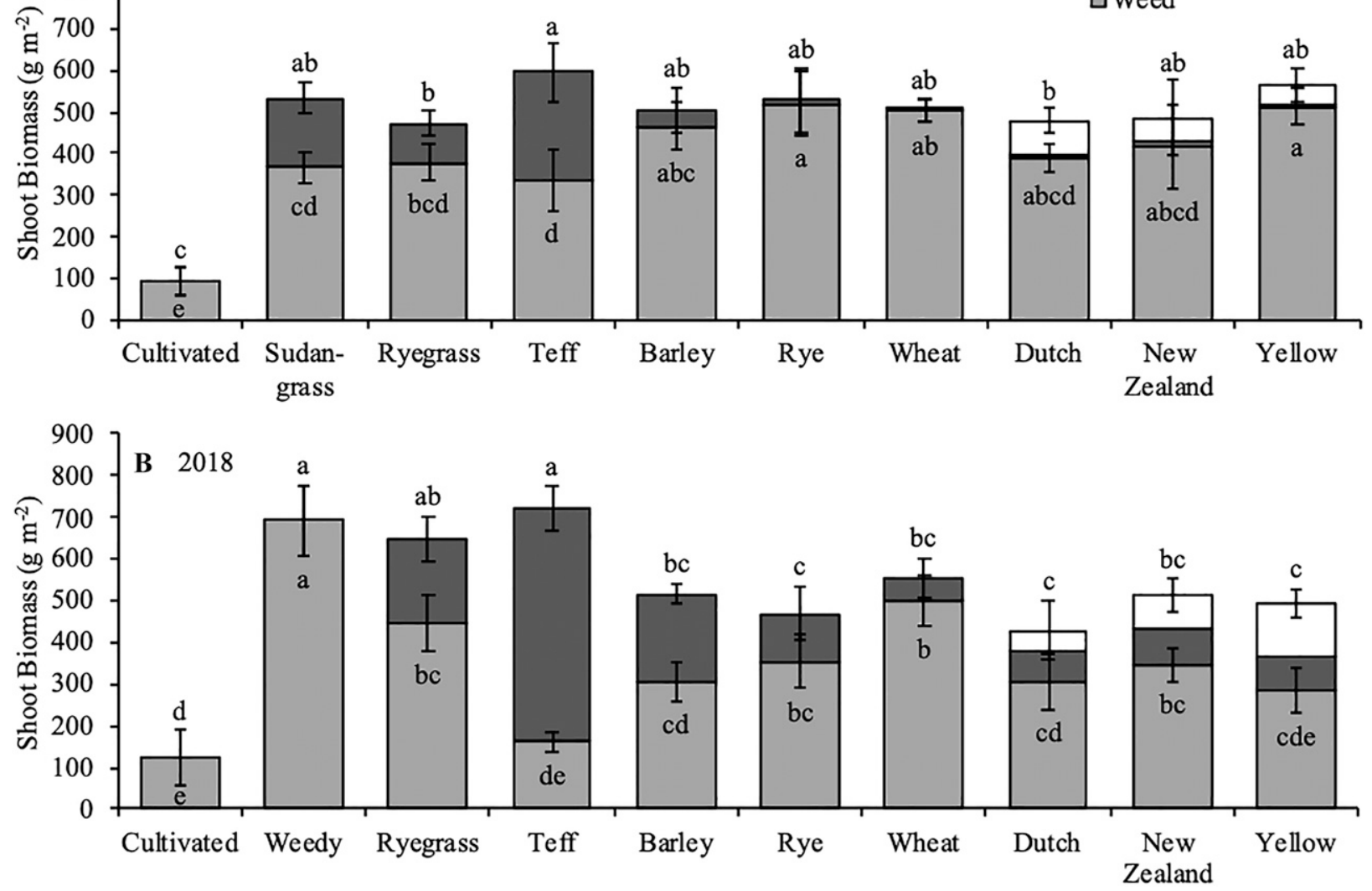

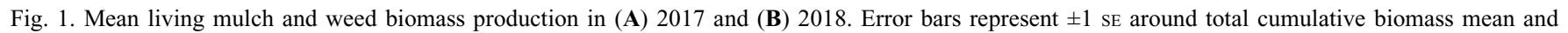
cumulative weed biomass mean. Letters above bars represent differences in cumulative aboveground biomass production $(P \leq 0.05)$. Letters within bars represent differences in cumulative aboveground weed biomass $(P \leq 0.05)$. Ryegrass $=$ Italian ryegrass; Dutch $=$ Dutch white clover; New Zealand $=$ New Zealand white clover; Yellow = yellow blossom sweet clover.

amount of total aboveground biomass. In 2018, teff and ryegrass produced similar amounts of total biomass as the weedy check, whereas all other treatments produced less total biomass than teff and the weedy check (Fig. 1). Weeds were a dominant component of total aboveground biomass produced in all living mulch treatments other than teff in 2018 (Fig. 1). The average heights of living mulch species before the first mowing event in 2017 and 2018, respectively, were as follows: sudangrass, $48 \mathrm{~cm}$ (2017 only); teff, 25 and $53 \mathrm{~cm}$; ryegrass, 13 and $26 \mathrm{~cm}$; rye, 13 and $30 \mathrm{~cm}$; wheat, 7 and $23 \mathrm{~cm}$; barley, 13 and $29 \mathrm{~cm}$; Dutch white clover, 6 and $14 \mathrm{~cm}$; New Zealand white clover, 5 and $13 \mathrm{~cm}$; and Yellow clover 6 and $23 \mathrm{~cm}$. In contrast, the average heights of weeds in nonliving mulch treatments before the first mowing were 28 and $43 \mathrm{~cm}$ in 2017 and 2018. With the exception of sudangrass in 2017 and teff in 2018 , weeds were generally taller than living mulch species in the field and determined the timing of mowing events.

Weed biomass suppression by living mulch treatments. The most abundant weed species in the field in both years included lambsquarters, pigweeds, crabgrass species (Digitaria spp.), ladysthumb (Polygonum persicaria L.) and Pennsylvania smartweed (Polygonum pensylvanicum L.). Regrowth of lambsquarters and pigweed could be effectively managed by mowing, but the adaptive plasticity of crabgrass, ladysthumb, and Pennsylvania smartweed allowed these weeds to escape the mower blade, expand into adjacent beds, and become problematic as the season progressed.

Cultivation provided greater in-season weed control than any living mulch treatment in 2017 (Fig. 1). Although a weedy check was not included in 2017, warm season grasses including teff did significantly reduce weed biomass relative to the rye living mulch treatment, which had minimal living mulch growth that year (Fig. 1). In contrast, other cool season grasses and clover-rye mixtures did not suppress weeds relative to rye in 2017. In 2018, all living mulch treatments reduced in-season weed biomass relative to the weedy check, and teff actually reduced in-season weed biomass to levels comparable to the cultivated control (Fig. 1). Results of a correlation analysis demonstrated that weed biomass was negatively correlated with living mulch biomass (Fig. 2).

Potential for competition with a cash crop. All plants growing between plasticmulched beds demonstrated the potential to compete with a cash crop through reductions of in-bed soil inorganic N (Fig. 3; Table 5) and moisture (Fig. 4; Table 6) relative to the

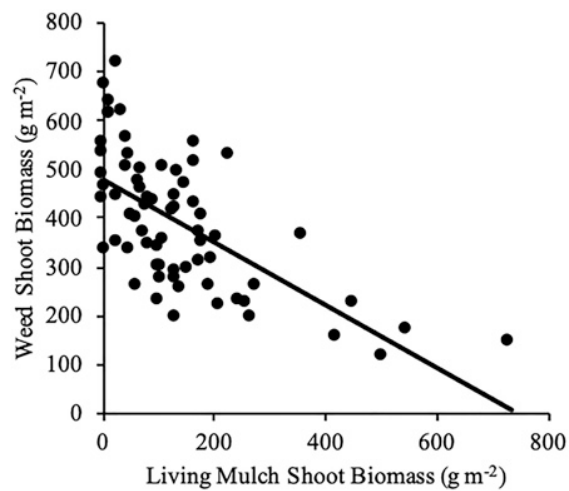

Fig. 2. Correlation between cumulative weed aboveground biomass and living mulch aboveground biomass. Data points combined for 2017 and 2018. Response: $y=-0.6438 x+$ $479.1, \mathrm{r}_{\mathrm{s}}=-0.64, P<0.001$.

cultivated control. The depletion of in-bed inorganic $\mathrm{N}$ and soil moisture resources by living mulch and weed growth increased as the season progressed, with differences becoming pronounced by late summer (Figs. 3 and 4).

By the end of the 2017 season, soil inorganic N levels within plastic-mulched beds were lower in all living mulch treatments 

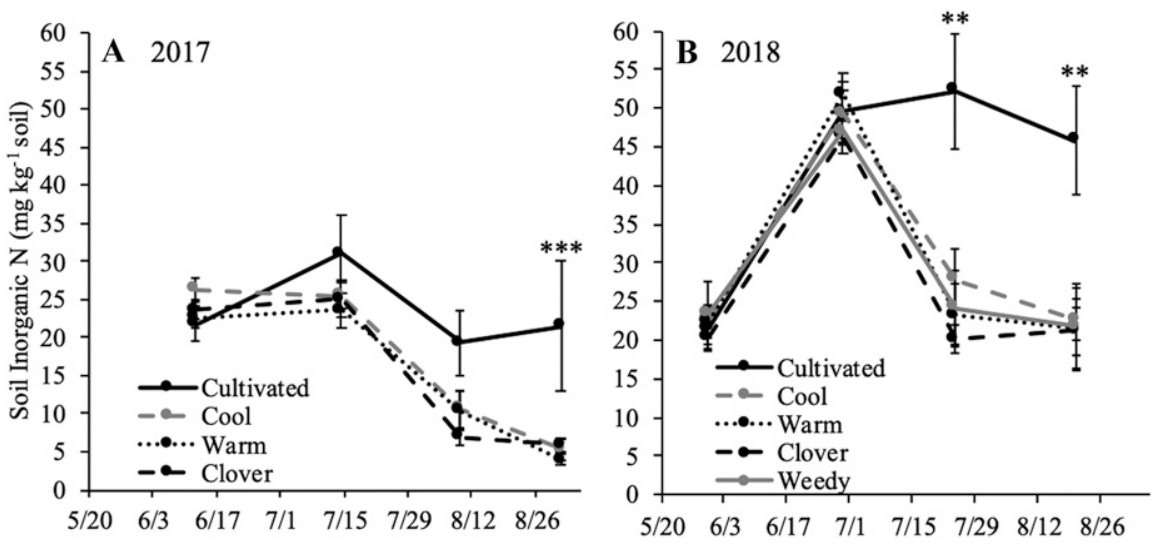

Fig. 3. In-bed soil inorganic N (nitrate plus ammonium) analyzed by functional group in (A) 2017 and (B) 2018. **,***Significant at $P \leq 0.01$ or 0.001 , respectively.

Table 5. Effect of between-bed treatment on soil inorganic $\mathrm{N}$ concentration in adjacent plastic mulchcovered beds. Only significant dates from analysis by functional group (Fig. 3) are reported.

\begin{tabular}{lccc}
\hline & $2017^{\mathrm{z}}$ & \multicolumn{2}{c}{2018} \\
\cline { 2 - 4 } Treatment & $31 \mathrm{Aug}$. & $\mathrm{mg} \mathrm{N} / \mathrm{kg} \mathrm{soil}$ & 20 Aug. \\
\cline { 2 - 4 } Cultivated & 21.5 & $52.2 \mathrm{a}^{\mathrm{y}}$ & $45.7 \mathrm{a}$ \\
Weedy & $-\mathrm{x}$ & $24.1 \mathrm{bc}$ & $21.7 \mathrm{bc}$ \\
Ryegrass & 4.9 & $19.7 \mathrm{bc}$ & $14.8 \mathrm{c}$ \\
Sudangrass & 4.0 & $-\mathrm{x}$ & - \\
Teff & 3.1 & $26.7 \mathrm{bc}$ & $28.0 \mathrm{~b}$ \\
Barley & 3.8 & $25.9 \mathrm{bc}$ & $22.6 \mathrm{bc}$ \\
Rye & 4.6 & $25.3 \mathrm{bc}$ & $26.2 \mathrm{bc}$ \\
Wheat & 7.6 & $32.4 \mathrm{~b}$ & $18.9 \mathrm{bc}$ \\
Dutch white clover & 5.8 & $23.6 \mathrm{bc}$ & $21.4 \mathrm{bc}$ \\
New Zealand white clover & 7.1 & $20.1 \mathrm{bc}$ & $18.6 \mathrm{bc}$ \\
Yellow sweet blossom clover & 4.9 & $16.5 \mathrm{c}$ & $23.6 \mathrm{bc}$ \\
\hline
\end{tabular}

${ }^{\mathrm{z}}$ Despite a significant effect of functional group on this date (Fig. 3), when 2017 data were analyzed by treatment the treatment by date interaction was not significant $(P=0.11)$ and the treatment main effect was marginally significant $(P=0.09)$. Therefore, means are presented for this date for consistency, but mean separation was not performed.

${ }^{\mathrm{y}}$ Means within the same column followed by the same letter are not significantly different according to Fisher's protected least significant difference test $(P \leq 0.05)$.

${ }^{\mathrm{x}} \mathrm{A}$ weedy check was not included in 2017 and sudangrass was not included in 2018.
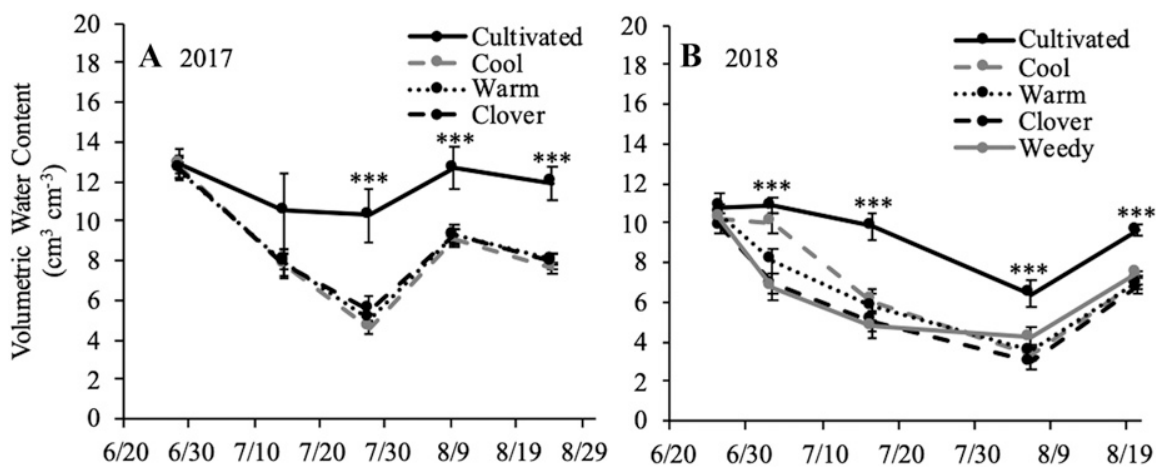

Fig. 4. In-bed soil volumetric water content analyzed by functional group in (A) 2017 and (B) 2018 . *** Significant at $P \leq 0.001$.

than the cultivated control, although no differences were observed among living mulch functional groups (Fig. 3A) or individual species (Table 5). Similarly in 2018, all living mulch treatments and the weedy check reduced in-bed soil inorganic $\mathrm{N}$ compared with the cultivated control by the end of the season
(Fig. 3B). However, some differences among individual living mulch treatments were also detected in that year including lower in-bed $\mathrm{N}$ levels in yellow clover than in wheat in July and lower in-bed $\mathrm{N}$ levels in the ryegrass treatment compared with teff in August (Table 5).
Differences in depletion of in-bed soil moisture in 2017 were also only detected between living mulch treatments and the cultivated control, with no differences among living mulch functional groups (Fig. 4A) or individual species with the exceptions of higher soil moisture in the teff treatment relative to wheat and ryegrass plots at the end of August (Table 6). In 2018, cool season grass treatments conserved in-bed soil moisture in early July compared with warm season grasses and clover-rye mixtures, with moisture levels similar to the cultivated control (Fig. 4B). However, by mid-July all living mulches reduced in-bed soil moisture compared with the cultivated control (Table 6).

\section{Discussion}

The purpose of this study was to evaluate the performance of different living mulch species for use between plastic-mulched beds. Of particular interest was variation among living mulch functional groups and individual species in terms of biomass production, weed suppression, and in-bed resource use. Three general themes emerged from this research. First, although living mulch treatments varied in the proportion of living mulch and weed biomass, nearly all resulted in the same amount of total aboveground biomass. Second, living mulches could reduce weed biomass, but weed suppression was rarely comparable to levels achieved with cultivation, varied considerably among living mulch species, and was driven largely by living mulch biomass production. Third, despite spatial separation and the physical barrier of the plastic mulch, all living mulches and weeds growing between plastic-mulched beds exhibited the potential to compete with a cash crop for in-bed soil resources.

Better establishment of living mulches in 2018 compared with 2017, measured by early-season density, may be explained by both higher seeding rates in some cases and greater precipitation shortly after sowing. The role of sufficient precipitation in living mulch establishment may have been particularly relevant on the coarse textured soil of the experimental site. We speculate that higher seeding rates in 2018 and more favorable establishment conditions explain greater suppression of early-season weed densities in 2018 compared with 2017. Alternatively, differences in soil temperature or moisture may have contributed directly or indirectly to differences in weed density across treatments in the 2 years.

A significant negative correlation between living mulch biomass and weed biomass was observed, demonstrating the potential importance of living mulch biomass production in weed suppression (Fig. 2). Negative correlations between cover crop and weed biomass have been shown often in previous research (Akemo et al., 2000; Hayden et al., 2012), suggesting that biomass production is an important factor driving differences in weed suppressive ability 
Table 6. Effect of between-bed treatment on soil volumetric water content in adjacent plastic mulch-covered beds. Only significant dates from analysis by functional group (Fig. 4) are reported.

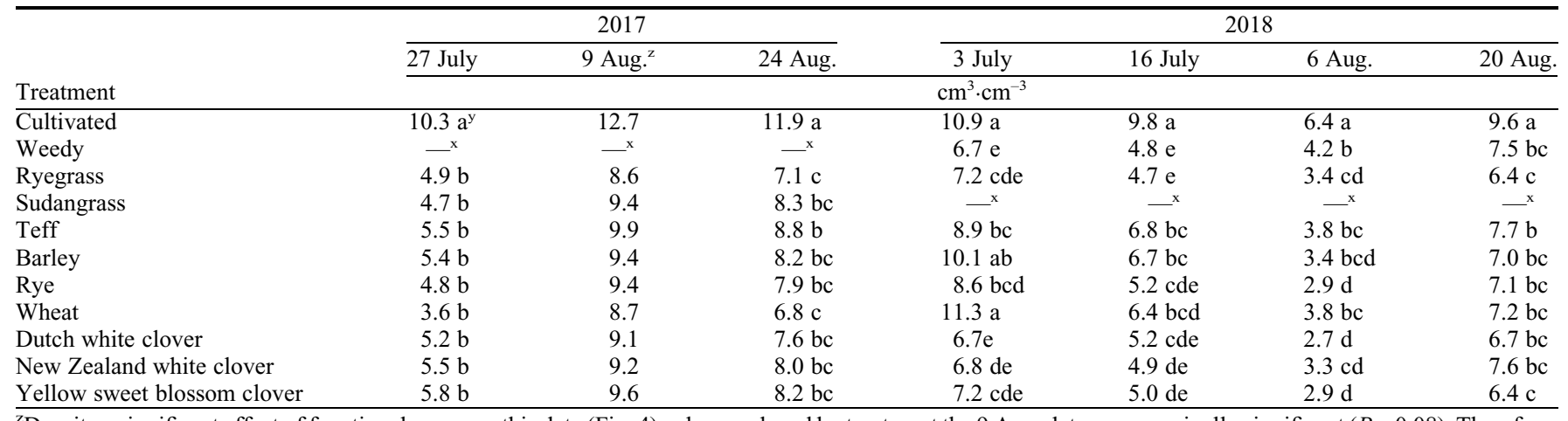

${ }^{\mathrm{z}}$ Despite a significant effect of functional group on this date (Fig. 4), when analyzed by treatment the 9 Aug. date was marginally significant $(P=0.08)$. Therefore, means are presented for this date but mean separation was not performed.

${ }^{\mathrm{y}}$ Means within the same column followed by the same letter are not significantly different according to Fisher's protected least significant difference test $(P \leq$ $0.05)$.

${ }^{\mathrm{x}} \mathrm{A}$ weedy check was not included in 2017 and sudangrass was not included in 2018.

among cover crop species. Among all the species evaluated in this study, teff accumulated the most living mulch biomass and least weed biomass (Fig. 1). Lower biomass accumulation among cool season grasses compared with warm season grasses in both years and compared with clover-rye mixtures in some cases was likely due to a combination of factors. First, these grasses are not well adapted to warm summer temperatures and maintain a relatively short stature in the absence of vernalization. As a result, they are likely less competitive than the warm season grasses with fast-emerging summer annual weeds. Second, the cool season cereal grasses used in this study are more susceptible to leaf rust (Puccinia triticina) than the warm season grasses. Rye, wheat, and barley became heavily infected with rust in July of both years, which likely further limited their growth.

In interpreting results of this study, it is important to keep in mind that living mulches were mowed three times during the season to mimic grower practice aimed at reducing crop competition from living mulches and weeds. Despite differences in weed suppression among living mulch treatments, mowing was still considered necessary to control the height of living mulches and weeds in all plots. Mowing likely encouraged a shift in the weed community to species that were more difficult to control by mowing, particularly in plastic mulch systems. Before mowing, the most common weeds were broadleaf summer annuals (common lambsquarters, mustards, and Amaranthus species). However, crabgrass, ladysthumb, and Pennsylvania smartweed were able to adjust their growth habit, allowing them to escape the mower blade, dominate as the season progressed, and produce seed by $\mathrm{Au}$ gust. This community shift is in line with previous findings by Butler et al. (2013), showing that repeated clipping of barnyardgrass, giant ragweed, and common lambsquarters reduced plant dry weight by as much as $82 \%$; however, clipping did not significantly reduce large crabgrass dry weight because of its ability to adjust its growth laterally.
With regard to potential competition with a cash crop, some subtle differences among living mulch treatments were observed, although given the notable weed pressure in living mulch treatments, we are unable to distinguish between living mulch and weed use of in-bed resources. For example, we observed delayed use of in-bed soil moisture by cool season grasses compared with other living mulch functional groups in 2018 (Fig. 4B); this effect may have been due to less resource use by the living mulches themselves or by greater early-season suppression of aggressive summer annual weeds in these treatments. Similarly, greater weed suppression in the teff treatment compared with the ryegrass and wheat in 2017 and yellow blossom sweet clover and ryegrass in 2018 might explain differences in soil moisture under plastic-mulched beds at the end season (Table 6). However, this explanation does not hold for comparably high levels of in-bed inorganic $\mathrm{N}$ in teff and wheat treatments at the end of 2018, even though weedy biomass in wheat plots was significantly higher than in the teff treatment (Fig. 1). Alternatively, differences in water resource use by the teff treatment may be explained by teff's relatively small and shallow rooting system (Roseberg et al., 2018) that was unable to access in-bed resources as easily as some other living mulches or weeds.

Regardless of these subtle differences among treatments, we found that plastic mulch did not act as an effective barrier to potential competition with a cash crop for soil resources. Rather, roots of between-bed living mulches and weeds were able to access soil $\mathrm{N}$ and moisture within plastic-mulched beds, reducing both resources relative to the cultivated control by the end of the summer. This effect may have been amplified in our raised bed system because much of the applied fertilizer and fertile topsoil was pulled into the plastic-mulched bed, leaving the between-bed area particularly nutrient deficient. In addition, regular irrigation likely resulted in more consistent and higher soil moisture under black plastic than between the beds, particularly later in the season. Under these circumstances, roots of both weeds and living mulches may have been stimulated to forage for resources under plastic-mulched beds. These results are consistent with previous research in which vegetable crop yield reductions have been common when a living mulch is grown between plastic-mulched beds (Butler, 2012; Law et al., 2006; Nelson and Gleason, 2018; Reid and Klotzbach, 2013; Reid, 2015; Reiners and Wickerhauer, 1995; Warren et al., 2015).

Our results suggest that supplemental fertilizer and irrigation inputs may be useful for overcoming competitive interference from living mulches or weeds. This approach has been evaluated with mixed success in studies with living mulches in the absence of plastic mulch (Brainard et al., 2004; Eberlein et al., 1992; Kurtz, 1952) as well as those in plasticulture systems (Warren et al., 2015). Although we cannot estimate precisely how much supplemental fertility or water would be required to overcome competitive interference, our study provides some guidance. For example, volumetric water content in both years of our study was reduced in all treatments from $\approx 5 \%$ to $12 \%$ in mid-July, which represents a difference of $\approx 60 \mathrm{~mm}$ of water per meter depth. This suggests that a vigorous cash crop growing during this period might require $\approx 30$ to $60 \mathrm{~mm}$ of additional water in living mulch treatments to avoid water stress.

In addition to species selection and supplementing the cash crop with water and fertility inputs, various management practices have been suggested to minimize competition and associated yield reductions caused by living mulches. These include suppressing living mulch and associated weeds through mowing, the use of selective herbicides, spatial separation of living mulch and cash crops, and delayed planting of living mulches (Masiunas, 1998). In this study, the physical separation provided by plastic mulch and the practice of regular mowing did not eliminate potential competition for soil resources with a cash crop, although they 
may have reduced potential for aboveground competition had a cash crop been present. Biazzo and Masiunas (2000) observed that mowing red clover, perennial ryegrass, and canola living mulches mitigated some pepper yield reductions compared with unmowed plots, but yields were still reduced compared with a conventionally tilled control. The use of mowing alone to mediate competition between a cash crop and living mulch has previously been questioned (Teasdale, 1996). Alternatively, the delayed planting of living mulches has been shown to at least partially alleviate cash crop yield losses in various crops including tomatoes (Gibson et al., 2011), cauliflower (Ciaccia et al., 2017), and broccoli (Brainard and Bellinder, 2004). The delayed use of in-bed resources by living mulches and weeds observed in our study suggests that belowground competitive inhibition may be reduced further if a living mulch was planted later, and between-bed areas kept weed-free for a critical period relevant to the management system. Future research investigating the critical weed-free periods for vegetation between plasticmulched beds would help optimize living mulches for important vegetable crops grown in plasticulture systems. However, maintaining the between-bed area as weed-free for some period would present its own challenges, including increased tillage events, the potential for herbicide injury, higher soil erosion potential during the weed-free period, and difficulty in establishing a living mulch later in the season (e.g., providing the necessary irrigation and labor requirements).

Although our study demonstrated that all full-season living mulch treatments grown between plastic-mulched beds had the potential to reduce cash crop yields through competition for in-bed soil resources, other ecosystem services provided by living mulches may offset this risk at the overall production system level. For example, living mulch can reduce soil and agricultural chemical runoff (Masiunas, 1998), provide aboveand belowground habitat for beneficials (Depalo et al., 2017; Frank and Liburd, 2005), and maintain cleaner harvesting conditions. In addition, our study showed organic matter inputs from living mulch and weed aboveground biomass can exceed $721 \mathrm{~g} \cdot \mathrm{m}^{-2}$ at a time when the soil would have otherwise been left bare. Although in our study weeds alone provided equivalent aboveground biomass to living mulches, substituting living mulch biomass for weed biomass may provide similar agroecosystem services while reducing contributions to the weed seedbank. Further investigation and economic quantification of these potential agroecological trade-offs will enable growers to make informed decisions specific to their unique production goals.

Few evaluations of multiple living mulch species within a plasticulture production system (Miles, 2012; Reid, 2015) and in the absence of plastic (Chase and Mbuya, 2008; Nicholson and Wein, 1983) have been conducted. We selected living mulches to repre- sent a range of desirable traits, although the list of species included was not exhaustive. Other living mulch species, functional groups, or living mulch mixtures could potentially fit well within this niche, provide alternatives to full-season living mulch management, and offer different management trade-offs. For example, Brennan and Smith (2018) evaluated the use of a mustard living mulch sown between raised plastic-mulched strawberry beds in organic production. The authors highlighted the benefits of mustard as a living mulch in organic systems where it can be killed effectively via mechanical means to provide a weed-suppressing dead mulch after considerable early-season growth. Similarly, buckwheat exhibits high biomass production early in the season before seed production, can be controlled fairly well via mowing or cultivation, and has been shown to provide effective control of summer annual weeds (Gibson et al., 2011). Aside from potential benefits of specific living mulch species not included in our study, mixtures other than the clover and rye may exhibit functional characteristics that could improve living mulch performance. For example, barley was able to suppress weeds early in the season, but a combination of rust and a low growth habit made it less competitive later. In contrast, teff did not establish as rapidly as barley but was able to consistently produce biomass and suppress weeds through the middle and end of the growing season. Therefore, mixtures of these two species might provide more consistent season-long biomass production and weed suppression than either alone. In practice, however, mixtures often provide no more weed suppression than the most suppressive species present (Lowry and Smith, 2018).

In summary, living mulches can reduce in-season weed pressure in plastic mulch systems, with all living mulches evaluated significantly reducing in-season weed biomass compared with the weedy check in 2018. However, weed suppression varied by species, and our living mulch treatments were rarely as effective as cultivation in suppressing in-season weed pressure. Differences between living mulch functional groups (warm season grasses, cool season grasses, and clovers) were not consistent, although clear differences in performance by individual species were observed. Teff produced the most biomass in both years, reduced inseason weed biomass more than any other living mulch screened, and was comparable to cultivation in terms of weed suppression in 2018. However, we also found that despite spatial separation and regular mowing, all treatments with plants growing between plastic-mulched beds demonstrated the potential to compete for in-bed resources. Addressing other strategies to reduce competition, such as delayed planting of living mulches relative to the cash crop or supplemental provisioning of resources, holds promise for optimizing both cash crop yields and weed control. In addition, assessing other living mulch species and other combinations of species may reveal relevant traits and synergies suited for use in plasticulture production. Finally, living mulches may provide other desirable ecosystem services alongside possible yield penalties. Therefore, future research assessing such trade-offs would aid growers in making informed decisions specific to their production and ecological goals.

\section{Literature Cited}

Adamczewska-Sowińska, K., E. Kołota, and S. Winiarska. 2009. Living mulches in field cultivation of vegetables. Veg. Crops. Res. Bul. 70(1):19-29.

Akemo, M.M., E.E. Regnier, and M.A. Bennett. 2000. Weed suppression in spring-sown rye (Secale cereal)-pea (Pisum sativum) cover crop mixes. Weed Technol. 14:545-549.

Arnold, G.L., M.W. Luckenbach, and M.A. Unger. 2004. Runoff from tomato cultivation in the estuarine environment: Biological effects of farm management practices. J. Exp. Mar. Biol. Ecol. 298(2):323-346.

Biazzo, J. and J.B. Masiunas. 2000. The use of living mulches for weed management in hot pepper and okra. J. Sustain. Agr. 16(1):59-79.

Brainard, D.C. and R.R. Bellinder. 2004. Weed suppression in a broccoli-winter rye intercropping system. Weed Sci. 52(2):281-290.

Brainard, D.C., R.R. Bellinder, and A.J. Miller. 2004. Cultivation and interseeding for weed control in transplanted cabbage (Brassica oleracea). Weed Technol. 18:704-710.

Brainard, D.C., J. Bakker, D.C. Noyes, and N. Myers. 2012. Rye living mulch effects on soil moisture and weeds in asparagus. HortScience 47:58-63.

Brennan, E.B. and R.F. Smith. 2018. Mustard cover crop growth and weed suppression in organic, strawberry furrows in California. HortScience 53:432-440.

Butler, R.A. 2012. Evaluation of cover crops and mowing as alternative approaches for weed control in organic tomato production. Purdue University, West Lafayette, IN, master's thesis. 1 Apr. 2019. <http://search.proquest. com.proxy1.cl.msu.edu/docview/1220693576/ abstract/162EA7431ABF4BB1PQ/1>.

Butler, R.A., S.M. Brouder, W.G. Johnson, and K.D. Gibson. 2013. Response of four summer annual weed species to mowing frequency and height. Weed Technol. 27(4):798-802.

Chase, C.A. and O.S. Mbuya. 2008. Greater interference from living mulches than weeds in organic broccoli production. Weed Technol. 22(2):280-285.

Ciaccia, C., H.L. Kristensen, G. Campanelli, Y. Xie, E. Testani, F. Leteo, and S. Canali. 2017. Living mulch for weed management in organic vegetable cropping systems under Mediterranean and North European conditions. Renew. Agr. Food Syst. 32(3):248-262.

Clark, A. (ed.) 2007. Managing cover crops profitably. 3rd ed. Sustainable Agriculture Research and Education program. College Park, MD.

den Hollander, N.G., L. Bastiaans, and M.J. Kropff. 2007. Clover as a cover crop for weed suppression in an intercropping design: I. Characteristics of several clover species. Eur. J. Agron. 26(2):92-103.

Depalo, L., G. Burgio, P. von Fragstein, H.L. Kristensen, M. Bavec, M. Robačer, G. Campanelli, and S. Canali. 2017. Impact of living mulch on arthropod fauna: Analysis of pest and beneficial dynamics on organic cauliflower (Brassica oleracea L. var. botrytis) in different European 
scenarios. Renew. Agr. Food Syst. 32(3):240247.

Eberlein, C.V., C.C. Sheaffer, and V.F. Oliveira. 1992. Corn growth and yield in alfalfa living mulch system. J. Prod. Agr. 5(3):332-339.

Frank, D.L. and O.E. Liburd. 2005. Effects of living and synthetic mulch on the population dynamics of whiteflies and aphids, their associated natural enemies, and insect-transmitted plant diseases in zucchini. Environ. Entomol. 34(4):857-865.

Gibson, K.D., J. McMillan, S.G. Hallett, T. Jordan, and S.C. Weller. 2011. Effect of a living mulch on weed seed banks in tomato. Weed Technol. 25(2):245-251.

Hartwig, N.L. and H.U. Ammon. 2002. Cover crops and living mulches. Weed Sci. 50(6): 688-699.

Hayden, Z.D., D.C. Brianard, B. Henshaw, and M. Ngouajio. 2012. Winter annual weed suppression in rye-vetch cover crop mixtures. Weed Technol. 26:818-825.

Kasirajan, S. and M. Ngouajio. 2012. Polyethylene and biodegradable mulches for agricultural applications: A review. Agron. Sustain. Dev. 32(2):501-529.

Kassambara, A. 2020. R package 'ggpubr': 'ggplot2' based publication ready plots (version 0.2.5).

Kurtz, T. 1952. The importance of nitrogen and water in reducing competition between intercrops and corn. Agron. J. 44(1):13-17.

Lamont, W.J. 2005. Plastics: Modifying the microclimate for the production of vegetable crops. HortTechnology 15:477-481.

Law, D.M., A.B. Rowell, J.C. Snyder, and M.A. Williams. 2006. Weed control efficacy of organic mulches in two organically managed bell pepper production systems. HortTechnology 16:225-232.

Leary, J. and J. DeFrank. 2000. Living mulches for organic farming systems. HortTechnology 10: 692-698.

Lindquist, J.L. 2015. MSU extension crops news letter for Northwest Michigan. <https://www.canr. msu.edu/uploads/234/43269/MSUE_Crops_ Newsletter_for_NW_MI_Jan_2015.pdf $>$.

Lowry, C.J. and R.G. Smith. 2018. Weed control through crop plant manipulations, p. 73-96. In
Non-chemical weed control. Academic Press, San Diego, CA.

MacLaren, C., P. Swanepoel, J. Bennett, J. Wright, and K. Dehnen-Schmutz. 2019. Cover crop biomass production is more important than diversity for weed suppression. Crop Sci. 59(2):733-748.

Masiunas, J.B. 1998. Production of vegetables using cover crop and living mulches-A review. J. Veg. Crop Prod. 4(1):11-31.

Miles, E.J. 2012. Living mulch: Its use in reducing phytophthora blight damage to bell pepper, suppressing weeds, and the effectiveness of using two-species mixtures versus monoculture. Cornell University, Ithaca, NY, master's thesis. 1 Apr. 2020. <https://ecommons.cornell. $\mathrm{edu} /$ bitstream/handle/1813/31021/ejm255.pdf? sequence $=1 \&$ isAllowed $=\mathrm{y}>$.

Nelson, K.A., R.J. Smeda, and R.L. Smoot. 2011. Spring-interseeded winter rye seeding rates influence weed control and organic soybean yield. Intl. J. Agron. 2011:Article ID 571973. doi: $10.1155 / 2011 / 571973$.

Nelson, H. and M. Gleason. 2018. Comparing between-row mulches in organic muskmelon and squash-year 2. Farm Prog. Rep. 2017(1). $<$ https://doi.org/10.31274/farmprogressreports180814-1942>.

Nicholson, A.G. and H.C. Wein. 1983. Screening of turfgrasses and clovers for use as living mulches in sweet corn and cabbage. J. Amer. Soc. Hort. Sci. 108:1071-1076.

Pfeiffer, A., E. Silva, and J. Colquhoun. 2016. Living mulch cover crops for weed control in small-scale applications. Renew. Agr. Food Syst. 31(4):309-317.

Paine, L.K. and H. Harrison. 1993. The historical roots of living mulch and related practices. HortTechnology 3:137-143.

Reid, J. and K. Klotzbach. 2013. Final Report for ONE12-171. 1 Apr. 2019. <https://projects.sare. org/project-reports/one12-171/>.

Reid, J. 2015. Final Report for ONE14-221. 1 Apr. 2019. <https://projects.sare.org/project-reports/ one14-221/>.

Reiners, S. and O. Wickerhauser. 1995. The use of rye as a living mulch to control weeds in bell pepper production. HortScience 30:892 (abstr.).
Rice, P.J., J.A. Harman-Fetcho, J.R. Teasdale, A.M. Sadeghi, L.L. McConnell, C.B. Coffman, R.R. Herbert, L.P. Heighton, and C.J. Hapeman. 2004. Use of vegetative furrows to mitigate copper loads and soil loss in runoff from polyethylene (plastic) mulch vegetable production systems. Environ. Toxicol. Chem. 23(3): 719-725.

Roseberg, R., S. Norberg, and B. Charlton. 2018. Teff grass for forage: Nitrogen and irrigation requirements. PNW 709. A Pacific Northwest Extension Publication.

Sarrantonio, M. 1992. Opportunities and challenges for the inclusion of soil-improving crops in vegetable production systems. HortScience 27:754-758.

Snapp, S.S., S.M. Swinton, R. Labarta, D. Mutch, J.R. Black, R. Leep, J. Nyiraneza, and K. O’Neil. 2005. Evaluating cover crops for benefits, costs and performance within cropping system niches. Agron. J. 97(1):322-332.

Steinmetz, Z., C. Wollmann, M. Schaefer, C. Buchmann, J. David, J. Tröger, K. Muñoz, O. Frör, and G.E. Schaumann. 2016. Plastic mulching in agriculture. Trading short-term agronomic benefits for long-term soil degradation? Sci. Total Environ. 550:690-705.

Tarara, J.M. 2000. Microclimate modification with plastic mulch. HortScience 35:169-180.

Teasdale, J.R. 1996. Contribution of cover crops to weed management in sustainable agricultural systems. J. Prod. Agr. 9(4):475-479.

Walters, S.A. and B.G. Young. 2008. Utility of winter rye living mulch for weed management in zucchini squash production. Weed Technol. 22(4):724-728.

Wan, Y. and S.A. El-Swaify. 1999. Runoff and soil erosion as affected by plastic mulch in a Hawaiian pineapple field. Soil Tillage Res. 52(1-2):29-35.

Warren, N.D., R.G. Smith, and R.G. Sideman. 2015. Effects of living mulch and fertilizer on the performance of broccoli in plasticulture. HortScience 50:218-224.

Wedryk, S. and J. Cardina. 2012. Evaluation of tef as a smother crop during transition to organic management. Weed Technol. 26(1):102109 . 